\title{
Effect of lysine feeding allowance on growth performance and carcass characteristics of growing pigs
}

\author{
O.I. Skoromna, O.P. Razanova, T.Y. Tkachenko \\ Vinnytsia National Agrarian University \\ Solar St. 3, Vinnitsa, Ukraine \\ E-mail: oksanas7777@rambler.ru, razanova elena@rambler.ru \\ Orcid: https://orcid.org/0000-0001-5552-9356
}

Received 16.10.2019 Accepted 14.12.2019

\begin{abstract}
The purpose of the study was the effect of lysine in the diets on the performance and slaughter indices of pigs during fattening. Young pigs of the experimental group, for the introduction to the diet of lysine, for 100 days of fattening had a greater live weight of $7.7 \mathrm{~kg}$, or $6.4 \%$. Control slaughter of pigs about the same indices of slaughter output of carcasses at the level of $84.0-86 \%$ in the experimental with a difference of slaughter weight by $4.3 \mathrm{~kg}$ in favor of the experimental group. A lower yield of internal fat and average fat thickness of $13.0 \%$ in experimental pigs was found, which confirms a more intense synthesis of muscle tissue. The content of total and bound moisture in muscle tissue was higher by $4.7 \%$ and $7.5 \%$, respectively, in the pigs of the experimental group against control, but lower by $2.5 \%$ of free moisture. The consequence of these indicators is a lower solid content of $4.5 \%$ in the experimental group of pigs.
\end{abstract}

Key words: Young pigs; Lysine; Live weight; Carcass weight; Marbling; Tenderness

\section{Introduction}

The high productivity of young pigs during the fattening is based on providing the diet with the necessary nutrients, in particular, crude protein, metabolism, vitamins, macro- and trace elements and other biologically active substances. Among these factors of high productivity of young pigs in fattening, an important role is played by amino acid nutrition and, in particular, lysine. So, if the content of lysine in the crude protein of the diet is taken as $100 \%$, then methionine with cystitis should be $60 \%$, threonine $-66 \%$, tryptophan $19 \%$, isoleucine $60 \%$, leucine $110 \%$, histidine $39 \%$, phenylalanine with tyrosine $120 \%$, valine $75 \%$, and surginine $42 \%$. This is the optimal ratio of essential amino acids in the diets of pigs, the percentage of lysine (Durst et al. 2003).

Proteins in animal tissues, including skeletal muscles, are in a dynamic state, which is based on their renewal, caused by the constant synthesis and disorder of muscle proteins, including structural proteins (Yanovich, 2000). Protein muscle tissue of pigs contains $8.7 \%$ of lysine, protein of cow's milk $-8.3 \%$, protein of beef $-8.6 \%$, and protein of chicken eggs as standard $-7.2 \%$, whereas grain forage wheat contains $-2.2 \%$ and barley $-3.6 \%$ of lysine (Kalashnikov et al., 2003).

The low content of lysine in cereal grains indicates that it is impossible to obtain high average daily increments of young pigs for growing and fattening using compound feeds only from cereal fodder. Due to the fact that any protein of a living organism consists of a chain of amino acids and their sequence is genetically determined, the absence or deficiency of at least one vital amino acid leads to disruption of protein synthesis. The primary structure of the protein cannot be synthesized, and unused amino acids enter the process of deamination. For the effective absorption of protein feed, it is necessary that the essential amino acids to be in proportion to each other. Thus, the proportion of essential amino acids for pigs in rearing and fattening pigs should be at least $47 \%$ of the total number of amino acids. At least $5 \mathrm{~g}$ of lysine should per $100 \mathrm{~g}$ of crude protein (Durst et al., 2003). At the same time, it should be noted that domestic standards of feeding pigs of different age groups regulate a lower level of lysine in crude protein compared with foreign ones. According to foreign companies the level of lysine in crude protein is $5.4-6.6 \%$, while according to O.P. Kalashnikov et al. (2003), the level of lysine is $4.0-4.6 \%$ in $1 \mathrm{~kg}$ of compound feed.

The high level of protein uptake of the diet of feed in the body of young pigs is also caused by the protein-energy ratio. With a high protein content in the diet, it can be fully utilized for the synthesis of muscle tissue and other pig body needs, even with optimal amino acid ratios. If there is insufficient protein in relation to energy, then the unused energy for protein synthesis is used for fat deposition and, first of all, in the abdominal (Durst et al., 2003).

\section{Protein}

Energy ratio is also expressed as lysine $(\mathrm{g})$ : digestible energy $\left(\mathrm{MJ}^{-1}\right)$ ratio. For young pigs, at the beginning of fattening, the optimum ratio of lysine to the exchange energy is $0.77 \mathrm{~g} \mathrm{MJ}^{-1}$, and at the end of fattening it is $0.7 \mathrm{~g} \mathrm{MJ}^{-1}$. The rate of utilization of metabolism for fat deposition is taken at the level of $74 \%$, and for the conversion of protein into body protein - 56\% (Durst et al., 2003). Feed additives that are introduced into pig feeds account for over one hundred different feed products that are constantly updated. Protein additives include betaine (Ostafin), a substance isolated from sugar beet molasses (Semenov et al., 2002).

Y.I. Babkov (2016) registered positive effect when added one $\mathrm{kg}$ per ton of compound feed, when evaluated the use of betaine in the growing of hybrid pigs. The use of protein vitamin mineral supplement (VMS) "Enervik" with carnitine during the pig growing increases the average daily gains by $6 \mathrm{~g}$ or $6.8 \%$ (Gutsol et al., 2016), and when using the feed additive "Minaktivit" the average 
daily gains increase by $95 \mathrm{~g}$ (Gutsol et al., 2016). Feeding by the compound feed "Intermix" increases the average daily increments by $32-67 \mathrm{~g}$ or by $4.2-8.7 \%$ (Goncharuk, 2016; Mazurenko et al., 2016).

The aim of the research was to check the possible increase in pig growth rate and slaughter quality with increasing of lysine content at the beginning and in the end of fattening.

\section{Material and Methods}

The studies were performed on young fattening pigs in the experimental farm "Pasichna" in Starosinyavsky district of Khmelnitsky region. Two groups of 15 pigs (Large White $x$ Landrace breed) were formed according to the principle of the method of analogous groups, taking into account the live weight of animals, age, sex, breed, fatness, and health status - 60-day-old nuts. The control group pigs consumed compound feed produced on the farm from wheat forage, silage corn grains, sunflower meal, BVMD (AgroVetAtlantik), experimental - additionally introduced into the diet premix with lysine. Feeding was carried out from $45 \mathrm{~kg}$ of live weight over 100 days.

Table 1. Feed composition, nutrition and content of essential amino acids, minerals, and vitamins.

\begin{tabular}{|c|c|c|c|c|c|c|}
\hline \multirow[b]{2}{*}{ Variables } & \multicolumn{2}{|c|}{ Start of fattening } & \multicolumn{2}{|c|}{ Middle fattening } & \multicolumn{2}{|c|}{ End of fattening } \\
\hline & control & experiment & control & experiment & control & experiment \\
\hline wet corn grain (kg) & 0.7 & 0.7 & 0.5 & 0.5 & & \\
\hline sunflower cake $(\mathrm{kg})$ & 0.2 & 0.2 & 0.2 & 0.2 & & \\
\hline BVMD 10\% Agrovetatlantic (kg) & 0.2 & 0.2 & 0.2 & 0.2 & 0.2 & 0.2 \\
\hline fodder wheat $(\mathrm{kg})$ & 0.9 & 0.9 & 1.2 & 1.2 & 3.1 & 3.1 \\
\hline BMP (premix) & & 0.1 & & 0.1 & & 0.03 \\
\hline Daily allowance (kg) & 1.9 & 1.9 & 2.1 & 2.2 & 3.3 & 3.3 \\
\hline Dry matter, kg & 1.5 & 1.6 & 1.7 & 1.8 & 2.8 & 2.9 \\
\hline Feed units (IVF) & 2.4 & 2.4 & 2.6 & 2.7 & 4.2 & 4.2 \\
\hline Dijestible energy, $\mathrm{MJ}^{-1}$ & 25.1 & 25.3 & 27.7 & 28.0 & 44.0 & 44.2 \\
\hline Crude protein, $\mathrm{g}$ & 320.0 & 324.0 & 358.0 & 362.0 & 497.0 & 499.0 \\
\hline Lysine, $\mathrm{g}$ & 15.5 & 21.3 & 17.2 & 23.6 & 20.6 & 24.0 \\
\hline Methionine + cystine, $\mathrm{g}$ & 9.3 & 9.8 & 10.2 & 10.7 & 13.1 & 13.4 \\
\hline Tryptophan, g & 3.3 & 3.3 & 3.6 & 3.6 & 4.5 & 4.5 \\
\hline Threonine, g & 11.8 & 12.3 & 12.9 & 13.4 & 15.4 & 15.7 \\
\hline$\%$ of JV: & & & & & & \\
\hline Lysine, g & 4.8 & 6.6 & 4.8 & 6.5 & 4.2 & 4.8 \\
\hline Methionine + cystine, $\mathrm{g}$ & 2.9 & 3.0 & 2.8 & 2.9 & 2.6 & 2.67 \\
\hline Tryptophan, g & 1.0 & 1.0 & 1.0 & 1.0 & 0.9 & 0.9 \\
\hline Threonine, $\mathrm{g}$ & 3.7 & 3.8 & 3.6 & 3.7 & 3.1 & 3.1 \\
\hline Calcium, g & 12.4 & 15.3 & 13.7 & 16.9 & 15.2 & 16.9 \\
\hline Phosphorus, g & 9.8 & 11.2 & 10.2 & 11.8 & 12.4 & 13.2 \\
\hline Iron, mg & 2168 & 2735 & 2322 & 2948 & 2420 & 2748 \\
\hline Copper, mg & 43.8 & 53.8 & 49.2 & 60.3 & 61.0 & 66.8 \\
\hline Zinc, mg & 196.6 & 241.6 & 215.2 & 264.9 & 253.0 & 279.1 \\
\hline Manganese, mg & 401.7 & 507.8 & 455.8 & 573.0 & 572.1 & 633.5 \\
\hline Cobalt, mg & 2.9 & 3.7 & 3.2 & 4.1 & 3.6 & 4.0 \\
\hline Iodine, mg & 1.8 & 2.2 & 1.9 & 2.5 & 2.1 & 2.4 \\
\hline Carotene, mg & 6.1 & 6.2 & 5.2 & 5.3 & 3.3 & 3.4 \\
\hline Vitamin A, mo & 11401.5 & 14821.5 & 16313.7 & 16381.1 & 13860.0 & 15840.0 \\
\hline Vitamin D, mo & 3.0 & 3.7 & 3.3 & 4.0 & 2.8 & 3.2 \\
\hline Vitamin $\mathrm{E}, \mathrm{mg}$ & 121.8 & 141.2 & 124.2 & 153.1 & 142.7 & 157.8 \\
\hline Vitamin B1, mg & 9.6 & 10.2 & 10.8 & 11.4 & 16.5 & 16.8 \\
\hline Vitamin B2, mg & 7.0 & 8.4 & 7.8 & 9.3 & 9.8 & 10.6 \\
\hline Vitamin B3, mg & 39.1 & 46.1 & 43.7 & 51.5 & 57.9 & 62.0 \\
\hline Vitamin B4, g & 1.50 & 1.5 & 1.8 & 1.8 & 3.0 & 3.0 \\
\hline Vitamin B5, mg & 143.0 & 156.0 & 161.0 & 174.0 & 211.0 & 219.0 \\
\hline Vitamin B12, $\mu \mathrm{g}$ & 28.5 & 37.1 & 31.5 & 41.0 & 34.7 & 39.6 \\
\hline
\end{tabular}


The content of lysine in the protein in the feed of the control group of pigs at the beginning of fattening was $4.83 \%$, and the experimental $-6.57 \%$ in the crude protein. Feeding of animals was carried out according to the established norms; keeping was in groups in premises for rearing and fattening of pigs. Distributed feed mixture (feed) in the feeder in dry bulk form once every few days twice a day, an average of 3.2-3.3 kg per head. Animal access to the water was free. Consumption of feed was taken after each weighing, and there were four of them, with the determination of gross and average daily increments ( $\mathrm{g}$ ), feed consumption per $\mathrm{kg}$ of live weight gain $(\mathrm{kg})$, exchange energy $\left(\mathrm{MJ}^{-1}\right)$ and lysine $(\mathrm{g})$. The increase in live weight of the animals was determined using group weighing data. Individual weighing of the animals was performed at laying and at the end of the experiment. According to the obtained results, the gross and average daily increments, feed costs per $\mathrm{kg}$ of growth were determined and a control slaughter of experimental pigs was conducted in order to study the slaughter qualities. Muscle tissue and internal organs were collected for laboratory testing during slaughter. Meat productivity and quality of slaughter products were evaluated according to the conventional method with determination before slaughter mass, slaughter weight and carcass yield. Qualitative and organoleptic characteristics of muscle tissue and internal organ morphological studies were studied on three typical animals from each group. Meat tenderness measurement was performed using the INSTRON 3342 testing system with Warner-Bratzler attachment, according to the method provided by Szalata et al. (1999). The physicochemical assessment also included meat color, determined with the Minolta CR 310, using the L*a*b* system (L* - brightness, a* - redness and b* - yellowness) (Itten, 2001). The amount of total pigments in the meat was determined after their conversion to hematin according to the Hornsey method (1956).

The composition of the feed, nutrition, content of essential amino acids, minerals and vitamins for pigs in the control and experimental groups in the beginning, in the middle, and after the fattening are given in Table 1 . The feed for both groups of young pigs was fairly balanced in terms of nutrition, content of crude protein, macro- and trace elements, and vitamins. The difference between compound feed for the control and relatively experimental pig groups is convincing regarding the lysine content of the crude protein. The results obtained were statistically analysed by calculating the arithmetic mean ( $\mathrm{x}$ ) and the standard deviation (s). Calculations were performed using one-way analysis of variance ANOVA. Tukey's test was used to determine the significance of the differences between the study groups. Calculations were done using the STATISTICA 10.0 (2011) computer software. The data in tables presented like average and standard deviation $(\mathrm{M} \pm \mathrm{m})$.

\section{Results}

The productive effect of the feed of the pigs of the experimental group with a high content of lysine in the crude protein was $11 \%$ higher than the control group. At the beginning of fattening, the content of lysine in the crude protein of the feed of the fattening pigs diet was $6.57 \%$ versus $4.83 \%$ in the control group or $29 \%$ more. Feed for pigs of both groups was balanced on all indicators of standard feeding, no doubt, except for the content of lysine in the crude protein. Confirmation of the balance of compound feed for pigs in the control group is the average daily gain of $748 \mathrm{~g}$. This is almost $750 \mathrm{~g}$ of average daily gain. As a rule, the productive effect of feed is evaluated first of all by the parameters of growth and development of young pigs and the cost of feed per unit weight gain. These indicators are presented in Table 2. The same table shows in parallel the daily average increments of pigs and the experimental group. Obtaining high average daily increments of pigs of the experimental group at the level of $827 \mathrm{~g}$ is justified by the increase in the content of lysine in the crude protein.

Table 2. Indexes of young pigs during the fattening $(n=13)$.

\section{Indexes}

Duration of fattening, days

Number of animals

Live weight of animal at the beginning, $\mathrm{kg}$

Live weight of one head at the end, $\mathrm{kg}$

$\%$ to control

Weight gain:

absolute, $\mathrm{kg}$

$\%$ to control

Average daily increase, $\mathrm{g}$

$\%$ to control

\section{Groups}

\section{Control}

100

15

$45.4 \pm 0.1$

$120.2 \pm 0.9$

74.8

100

748

100

\section{Experimental}

100

15

$45.2 \pm 0.20$

$127.9 \pm 0.9$

106

82.7

111

827

111

Young pigs of the control group for 100 days of fattening reached a live weight of $120.2 \mathrm{~kg}$, and experimental for the same period $127.9 \mathrm{~kg}$, i.e., the difference is $7.7 \mathrm{~kg}$, or $79 \mathrm{~g}$ more. The difference is convincingly indicative of the important role of balancing diets for pigs in fattening lysine in dietary protein. The high productive effect of high lysine compound feed (Table 1) is the metabolism of pigs. Analyze the total content of protein and its fractions and the content of inorganic phosphorus, total calcium, glucose and urea in the blood of pigs of both groups (Table 3).

Analysis of the morphological and biochemical parameters of the blood (Table 3) showed a tendency of increasing the content of total protein, albumin, $a$ and $\beta$ - globulins, and inorganic phosphorus and total calcium were almost at the same level. Indicators of a clinical nature - erythrocytes and leukocytes were in compliance with the physiological norm. A lower $24 \%$ level of urea in the blood of pigs in the experimental group indicates a lower level of amino acid disinfection and, as a consequence, a higher level of protein synthesis in muscle tissues and a higher increase in live weight of animals. The difference of $79 \mathrm{~g}$ of average daily gain in favor of pigs of the experimental group is confirmed by the higher content of lysine in the compound feed. Thus, the content of lysine in the raw protein of the feed of the pigs is a limiting factor for their high productivity and, obviously, the production of less fat and more meat. After 100 days of pig fattening, a control slaughter was performed and samples of muscle tissue were taken to determine the necessary parameters (Handbook, 2004). The results of control slaughter pigs are presented in Table 4. 
Table 3. Morphological and biochemical parameters of blood in experimental pigs, $(n=3)$.

\section{Indexes}

Erythrocytes, T / I

Hemoglobin, g / I

Total protein, $\%$

Protein fractions:

albumins, \%

a - globulins, $\%$

$\beta$ - globulins, $\%$

Inorganic phosphorus, $\mathrm{mg} \%$

Total calcium, mg\%

Urea, mg\%

Glucose, mg\%

\section{Groups}

\section{Control}

$$
5.2 \pm 0.7
$$

$112 \pm 11.4$

$7.58 \pm 0.5$

$46.2 \pm 3.1$

$48.4 \pm 2.3$

$15.4 \pm 3.4$

$15.7 \pm 1.4$

$8.77 \pm 0.9$

$13.6 \pm 0.4$

$25.0 \pm 0.3$

$66.8 \pm 1.7$

\section{Experimental}

$5.3 \pm 0.7$

$112 \pm 12.4$

$7.69 \pm 0.6$

Table 4. Control slaughter indices of experimental pigs, $(n=3)$.

\section{Indexes}

Dead weight, $\mathrm{kg}$

Slaughter weight, kg

Carcass weight, $\mathrm{kg}$

The output of the carcass, $\%$

Internal fat, $\mathrm{kg}$

Mean fat thickness, $\mathrm{mm}$

\section{Groups}

\section{Control}

$$
\begin{gathered}
120.2 \pm 0.9 \\
101.2 \pm 1.2 \\
85.0 \pm 1.3 \\
84.0 \pm 2.2 \\
1.9 \pm 0.1 \\
34.6 \pm 0.6
\end{gathered}
$$

\section{Experimental}

$127.9 \pm 0.9$

$105.5 \pm 0.9$

$90.7 \pm 1.4$

$86.0 \pm 1.9$

$1.4 \pm 0.1$

$30.2 \pm 0.8$

Control slaughter of pigs at first glance indicates the same indices of slaughter output of carcasses $84.0 \%$ in the control group and $86 \%$ in the experimental with a difference of slaughter weight by $4.3 \mathrm{~kg}$ in favor of the experimental group. However, it is necessary to analyze a lower yield of internal fat and average fat thickness of $13.0 \%$ in experimental pigs, which confirms the more intense synthesis of muscle tissue. In the control group of pigs, the processes of amino acid deamination took place at a higher level than in the pigs of the experimental group. Comparing the increase in average daily increments by $10.5 \%$ higher in the group of pigs with a higher content of lysine in compound feed against control, and a decrease in fat thickness by $13.0 \%$ is the body's response to the reduction of fat deposition, i.e., the intensity of lipid metabolism.

Table 5. Biochemical indexes of the longest back muscle of fattened pigs, $(n=3)$.

\section{Indexes}

Total moisture, $\%$

including free, $\%$

linked, $\%$

Dry matter, $\%$

$\mathrm{pH}$

Intensity of color, E 100

Tenderness, $\mathrm{N}$ per $\mathrm{cm}^{2}$

Marbling

Protein,\%

Fat,\%

Ash,\%

\section{Groups}

\section{Control}

$69.2 \pm 1.8$

$18.7 \pm 0.8$

$50.5 \pm 1.3$

$30.8 \pm 10.1$

$5.68 \pm 0.2$

$66.9 \pm 3.1$

$256.6 \pm 12.4$

$19.8 \pm 0.7$

$20.4 \pm 0.4$

$5.3 \pm 0.2$

$5.3 \pm 0.2$

\section{Experimental}

$73.7 \pm 2.2$

$16.2 \pm 0.8$

$57.5 \pm 1.7$

$26.3 \pm 1.3$

$5.74 \pm 0.1$

$65.4 \pm 3.4$

$262.6 \pm 18.8$

$18.4 \pm 2.0$

$22.8 \pm 0.4$

$4.1 \pm 0.3$ 
The results of studies (Table 5) of the longest back muscle indicate that the total moisture content was higher by $4.7 \%$ in the pigs of the experimental group against control, but lower by $2.5 \%$ free moisture, along with the associated moisture was more than $7.5 \%$ in the muscle tissue (meat) of pigs of the experimental group. The consequence of these indicators is a lower solid content of $4.5 \%$ in the experimental group of pigs. Indicators of intensity of color, tenderness and marbling practically had no significant deviations between groups. Attention should be paid to a higher protein content of $2.4 \%$ in the muscle tissue of pigs of the experimental group and a natural fat content of $1.2 \%$. This is because the animals in the control group used some of the protein, due to their lower lysine content, to spend on fat in their muscle tissue as well as internal fat. The imbalance of crude protein with the essential amino acid lysine is significantly reduced by the productivity of all farm animals, but pigs and poultry are the most responsive. Taking into account the rate of need for piglets in lysine in the crude protein of the diet, the protein in barley lacks $20 \%$ $\left(1.2 \mathrm{~g} \mathrm{~kg}^{-1}\right)$, oats $30 \%\left(1.7 \mathrm{~g} \mathrm{~kg}^{-1}\right)$, corn $40 \%\left(1.9 \mathrm{~g} \mathrm{~kg}^{-1}\right)$ and sunflower meal is about $30 \%$. In terms of total protein content of nitrogen in essential amino acids, soybean meal is only inferior to animal products (chicken, milk, meat, and fish), but exceeds that of other oilseeds. In Table 1 we presented the composition of the feed for pigs in the control group and the introduction of soy meal based protein additives in it. The lysine content was quite high but did not provide the need for more than $6.0 \%$ crude protein. Such a level of lysine can be ensured only by introducing into the compound feed a certain level of lysine of synthetic or microbial origin, that is, in the composition of the corresponding premix. The balance of the diet in the content of macro and microelements for pigs of both groups affects the optimum level of up to $3.5 \%$ ash in meat (Table 5), whereas the imbalance leads to an ash content of $1.3-1.6 \%$ in $g$ ulcer tissue in the experiments of many authors (Begma, 2009).

\section{Conclusion}

At intensive fattening of young pigs the content of lysine in the crude protein should be at the growing, beginning and middle of the period of fattening at the level of more than $6.0 \%$, and in the final period up to $4.5 \%$. With the same crude protein content, the average daily increments of experimental pigs with a higher meat yield and with a lower fat content, and with a lower fat content, increase by $10.5 \%$.

\section{References}

Babkov, Y. (2016). Productive qualities of hybrid piglets on the growth for betaine use. Agrarian Science and Food Technologies, 3 (94), 11-16 (in Ukrainian).

Begma, N. (2009). The use of by-products of corn and mustard processing in the feeding of pigs. Lviv: Stepan Gzhytskyi National University of Veterinary Medicine and Biotechnologies (in Ukrainian).

Durst, L., Wittman, M. (2003). Feeding farm animals. Vinnytsia, New Book (in Ukrainian).

Gutsol, A., Bilyavtseva, V. (2016). Efficiency of the use of VMS "Enervik" in growing of meat pigs. Agrarian Science and Food Technologies, 3 (94), 18-28 (in Ukrainian).

Gutsol, A., Bondarenko, V. (2016). The use of "MinVivit" VMS in feeding of young pigs. Agrarian Science and Food Technologies, 3 (94), 29-39 (in Ukrainian).

Goncharuk, A. (2016). Productivity and hematological parameters of young pigs in feeding the BVMD "Intermix". Agrarian Science and Food Technologies, 3 (94), 29-39 (in Ukrainian)

Handbook: Physiological and biochemical methods of research in biology, stockbreeding and veterinary medicine. (2004). Vlizlo, V. V. (Ed.). Lviv: Institute of animal biology National Academy of Agrarian Sciences (in Ukainian)

Hornsey, H.C. (1956). The colour of cooked cured pork. I. Estimation of the nitric oxidehaem pigments. J. Sci. Food Agr, 7, 534540.

Itten, J. (2001). The elements of color: a treatise on the color system of Johannes Itten, based on his book The art of color. New York, USA, John Wiley and Sons.

Kalashnikov, A.P., Fisinin, V.I., Shcheglov, V.V., \& Kleymenov, N.I. (ed.) (2003). Norms and rations of feeding of farm animals. Moscow (in Russian).

Lugova, G.A., Karpets, Yu.V., Weiner, A.A., \& Koglupayev, Yu.E.. (2017). Induction of resistance of millet plants to abiotic stressors by the action of jasmine acid (pp. 346-353). In: Morgun V.V. (ed.) Plant physiology: achievements and new directions of development; in a row. Kyiv: Logos (in Ukrainian)

Mazurenko, M.A., Gutsol, N.V., \& Datsyuk, I.V. (2016). Effectiveness of feeding Intermix premixes of pigs for meat production. Agrarian Science and Food Technologies, 3 (94), 46-57 (in Ukrainian)

Mikołajczak B., Mesyński A., Rzosińska E., Bartkowiak Z., Danyluk B. (1999). Tenderness of pig meat with differentiated meatiness. Roczniki Instytutu Przemysłu Mięsnego i Tłuszczowego, 36, 61-76 (in Polish).

Petukhova E.A., Bessarabova V.F., Khamneva L.D. (1989). Zootechnical analysis of feed: a manual for students. Moscow: Agropromizdat (in Russian).

Semenov, S.O., Vyslanko, O.O., Bulavkina, T.P., \& Chapovsky, M.I. (2002). The use of betaine preparation for raising semen production of boars. Bulletin of the Poltava State Agrarian Academy, 5-6, 70 (in Ukrainian).

Szalata M., Pospiech E., Łyczyński A., Urbaniak M., Frankiewicz A., Mikołajczak B., Mesyński A., Rzosińska E., Bartkowiak Z., Danyluk B. (1999). Tenderness of pig meat with differentiated meatiness. Roczniki Instytutu Przemysłu Mięsnego i Tłuszczowego, 36, 61-76 (in Polish).

Yanovich, V.G., Sologub, L.I. (2000). Biological bases of nutrient transformation in ruminants. Lviv: Triad Plus (in Ukrainian).

\section{Citation:}

Skoromna, O.I., Razanova, O.P., Tkachenko, T.Y. (2019). Effect of lysine feeding allowance on growth performance and carcass characteristics of growing pigs. Ukrainian Journal of Ecology, $9(4)$, 646-650.

(cc) $\mathrm{EY}$ This work is licensed under a Creative Commons Attribution 4.0. License 